\title{
Prophets competing against each other in a commercial age: Have some prophets or neoprophetic churches gone too far?
}

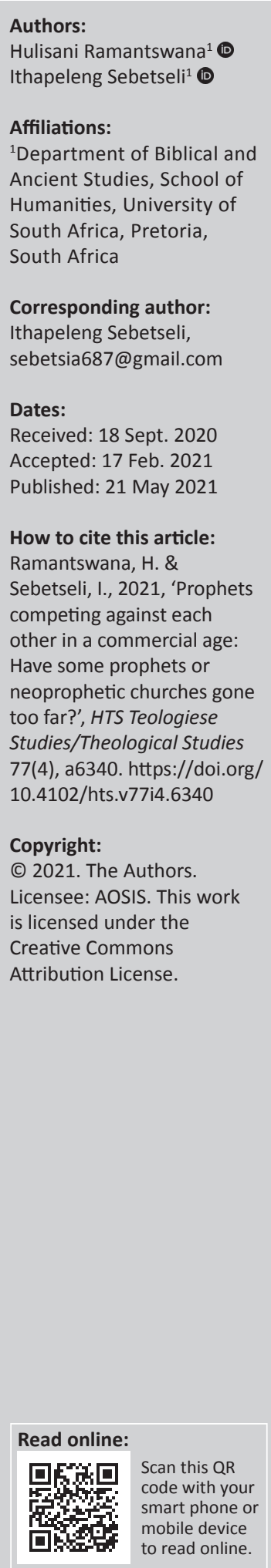

In recent years, there is growing concern with some of the bizarre practices in some neoprophetic churches. Amongst the concerns raised are the bizarre practices and the commercialisation of churches with claims that churches are being turned into lucrative businesses. In this article, the relationship amongst prophets, churches and commerce is explored, focusing on competitive behaviour in an open market or free market. The article engages the following issues: firstly, the issue of religious marketing in the context of a free market and consumerism; secondly, branding faith in relation to competition between churches and brands of prophets and thirdly, fraudulent activities facilitated by prophets.

Contribution: The article provides a critical assessment of the practices of prophets and neoprophetic churches considering their commercial interests. Thus, the study points to the intersection between religion and commerce.

Keywords: Christian faith; religion; Christian church; religious marketing; consumerism.

\section{Introduction}

When you think you have seen it all, something bizarre happens in some South African churches. The so-called prophets or pastors bring petrol and detergents like Dettol to a church setting and offer their congregants although they quench the soul's thirst or have a healing effect. Grass, rats, dog meat and snakes are given to the congregants to eat although they feed souls. A product such as Doom sprayed on people although they have healing effects. Miraculous claims of peoples' hands and legs lengthened are becoming signature marks of the neoprophets' power. Miracle fire happens during a church service as Elijah's miracle of fire is replicated to prove that the man of God is a true prophet. Pastors or prophets have become the creators of millionaires through prosperity gospel, miracle money and investment schemes. Still, something else happens. On 24 February 2019 a man supposedly resurrected from the dead at the Alleluia Ministries International at Sandton, the new hub of South Africa's gold city. The coming back to life of a dead man reached its climax in plain sight of the congregants who filled the church auditorium and the overflow area and when the event was broadcasted by rolling cameras. Inside the church auditorium, the stage was filled with wheelchairs and other items to symbolise the healing power performed through the pastor. The missing item from the items set on the stage was a coffin. This was expected to be a climactic moment - and climactic it was for those who filled the auditorium and the countless followers who were glued to their televisions or computer screens. ${ }^{1}$ Still, something else happens, prophet Shepherd Huxley Bushiri and his wife Mary, who are facing fraud and money laundering cases in South Africa, escaped to home country Malawi. In doing so, prophet Bushiri and his wife violated their bail conditions and became wanted fugitives.

The bizarre practices mentioned here draw scrutiny from popular media and from those within academic circles (Kgatle 2017; Resane 2016). The practices also attracted the attention of the Commission for the Promotion and Protection of the Rights of Cultural, Religious and Linguistic Communities (CRL Rights Commission). ${ }^{2}$ Cultural, Religious and Linguistic Rights Commission started probing into religion and the abuse of people's belief systems in the religious sector. As the probe is crafted under the general term 'religion', it is clear from the report that the problem is not so much with all religions represented in South Africa, but it is with the Christian religion

1.The miracle of the man who resurrected from the dead happened on the day on which Alleluia Ministries International was celebrating its seventeenth anniversary, just after the completion of forty-day fast.

2.The CRL Rights Commission is a Chapter Nine institution in terms of Section 181 of the Constitution of the Republic of South Africa (Republic of South Africa 1996). For the functions of the CRL Rights Commission, see Constitution, Section 185 (Republic of South Africa 1996:94). 
(see CRL Rights Commission 2017). Thus, it is not necessary to beat around the bush; the CRL Rights Commission should have been specific, stating that it is a problem within Christianity, rather than giving the impression that the concerns are with regard to all religions. ${ }^{3}$ Furthermore, the CRL Rights Commission should have zoomed into the particular Christian churches as the concerns relate to specific churches and their leaders : the neoprophetic or neopentecostal churches and their prophets (or pastors).

In its probe, the CRL Rights Commission did not merely set out to investigate the abuse of people's belief systems and the issue of religion and commerce considering the wealth that some religious practitioners are amassing (CRL Rights Commission 2017:6). In so doing, the relationship between religion and commerce is put into question. This article is more interested in the relationship between the neoprophetic churches and commerce, focusing on competitive behaviour in an open market or free market. In this environment, neoprophetic churches and their prophets present themselves as brands that are pushing the boundaries in religious freedom and practice.

It is crucial to uncover some of the underlying factors influencing the bizarre practices within the neoprophetic churches. This article engages with the issue of bizarre practices as symptomatic of the competition amongst prophets, which is influenced by the desire for a competitive place in the religious market share. The following issues are engaged with: firstly, the issue of religious marketing in the context of a free market and consumerism; secondly, branding faith in relation to competition between churches and brands of pastors and thirdly, fraudulent activities with regard to the commercialisation of religion. The underlying presupposition is that various dimensions of human life are intricately linked, thereby forming a complex network in which religion and commerce should not be viewed as autonomous items that have nothing to do with each other. ${ }^{4}$

\section{Commercialisation of religion in a consumer culture and religious marketing in South Africa}

Resane (2016) regarded the bizarre practices as emanating from the anti-institutionalism, anti-intellectualism, antinomianism and antisacramentalism. As Resane argues, such churches' prophets or pastors operate without institutional balance and checks, with no academic rigour, disregarding moral standards in culture and a preference of

3.In our view, it is unnecessary to paint other religions and other religious practitioners with the same brush when the problem is identified specifically with Christian religion or faith. This is especially important, given that the CRL Rights Commission does not report any concerning practices in African traditional religion, Islam, Judaism, Buddhism or any other non-Christian religion.

4.As Carrette and King (2005:10) argued,'...fixed categories such as "religion," "politic $s$ " "economics" etc , even though people often use these terms as if they refer to distinct spheres of human life. For analytic purposes such distinctions can re usefu in in order to sepate operate. W should not be "rectly " "pol the complexity of the culture itself. When we use terms such as "religion", "politics" and "economics", the impression can be created that these are autonomous realms of human cultural experience, which bear little or no relation to each other'. divine directives. For Kgatle (2017), the bizarre practices in the neoprophetic churches are fuelled by the socio-economic factors such as unemployment, lack of medical aid, poverty as the desperate and vulnerable are drawn to the neoprophetic churches in the hope of finding deliverance. Whilst both Resane and Kgatle highlight essential aspects, the matter also needs to be interrogated in the light of the consumer culture that influences the churches' practices. The bizarre practices have to be viewed as part of the Christian circles' competitive behaviour as neoprophets seek more significant faith share amongst the populace. Therefore, the bizarre practices cannot be divorced from the broader discussion on the commercialisation of religion in South Africa in the light of neoliberalism and consumerism dictates.

Neoliberalism, which has become a dominant political paradigm of our time, has key values such as individual entrepreneurial freedom, privatisation, deregulation, free market and free trade. In the South African context, post1994, the socialist-oriented African National Congress started embracing the neoliberal political paradigm to open South Africa to the free market (Harvey 2005). ${ }^{5}$ The embracing of neoliberalism cemented by the shift from Reconstruction and Development Programme (RDP) to Growth Employment and Redistribution (GEAR) as focus shifted towards promoting fiscal austerity, export and privatisation (Narsiah 2002:31). As Harvey (2005) argued, neoliberalism has resulted in capitalism having a dominant influence on political, social and cultural consciousness. To these may be added religion as well. By intensifying capitalism into every sphere of life, neoliberalism thus pulls everything towards the market's domain. This implies that a certain form of spirituality has emerged, a spirituality of capitalism, which promotes atomisation, selfinterest, corporatism, utilitarianism, consumerism, quietism, political myopia, thought-control or accommodation (Carrette \& King 2005). In the current environment, religion competes with businesses or corporate capitalism, politics and so on. Religion faces the threat of takeover by the business world, in which things are privatised and sold off as commodities and control from the political sphere. Still, to survive, it also has to learn to play the game within the neoliberal market.

During the colonial and apartheid era, Christianity was the state religion in the South African context. This, however, did not imply that other religions did not have room to operatethey operated, but not as official state religions. The special position that Christianity occupied during the time was evidenced by featuring biblical studies in school curricula at both primary school and secondary or high school and at the higher education level. Furthermore, Christianity also played a great role in establishing schools and universities, which were later taken over by the government. Thus, Christianity was afforded an advantage over its competitors and so it had a competitive edge, as it was intertwined with the colonial project. The filling of minds with Christian ideas was not merely a matter of one's choice about God, but one was

5.As Harvey (2005:29) observed, the International Monetary Fund and the World Bank were the primary institutions urging the adoption of neoliberal ideology and the free market. 
trapped in a matrix in which Christian ideas permeated every sphere of life. People came to identify with Christianity not as a matter of choice but as a matter of survival.

When South Africa transitioned into a secular or a 'religiously neutral'democracy in 1994, Christianity was dethroned as the state religion, becoming one religion amongst other religions. The fact that South Africa is a secular state does not imply that the citizenry has become irreligious. The people's longing for faith or spiritual experience remains. South Africa has not gone through the same route as Europe, in which secularisation has resulted in the decline of organised religion. As Einstein (2008:17) noticed, 'secularisation is not a one-way street. Rather, secularisation is a mutual process the sacred becoming more secular and the secular becoming more sacred' (see also Oswalt2003). In our context, religion has continued to thrive amidst the secularisation of the state or what others refer to as a 'religiously neutral state'(see Van der Vyver \& Green 2008:345). In a religiously neutral state, people have the freedom of religion, and their choice of religion depends on what suits their individual needs.

The Constitution of the Republic of South Africa (RSA) guarantees freedom of religion for as long as things are performed in a manner consistent with the Bill of Rights. In providing for the freedom of conscience, religion, thought, belief and opinion, the RSA Constitution to some extent follows the First Amendment to the United States Constitution, which speaks about the freedom of religion, speech and the press:

Congress shall make no law respecting an establishment of religion or prohibiting the free exercise thereof or abridging the freedom of speech or the press, or the right of the people peaceably to assemble and to petition the government for a redress of grievances. (see USA 1791)

The Constitution's guarantee and protection of religious freedom does not have to be viewed as implying that religious freedom should not be regulated. As Cohen (2002:394) noticed, the state still retains the right to protect its citizens' health, safety and welfare by providing necessary regulatory frameworks. Furthermore, although the Constitution guarantees religious freedom, religious freedom may still be regulated when religious practices cross border into other areas, such as medicine or revenue. Within the American context, Cohen (2002) pointed out the following concerning the relationship between religious practices and healthcare:

Religious practices involving health are frequently swept into the conceptual category of medicine and its regulation. In this way, the legal system checks individual healing choices, and challenges healing impulses in both medical, as well as religious, personnel that represent potential incursions on state determinations of the legally accepted boundaries of healing. (p. 395)

However, this does not imply that there are no challenges within the American system in terms of defining the relationship between religious healing practices and professional medical practice. For example, within the professional health sector diagnoses are made in terms of the anatomical or physiological, psychologicalor social relationships and hardly in terms of the relationship between the patient and deity (Aldridge 2000:9). In our South African context, it is common for traditional healers to make diagnosis of their patients in terms of their relationship with their ancestors. Some people also fail to receive help from the professional healthcare service, instead they find help from traditional healers.

In guaranteeing the freedom of religion, the RSA Constitution implies that Christianity has to compete with other religions in the religious market place. Thus, the Christian church has to compete to maintain its edge over other religions. The statistical information released by STATSSA in 2014 showed that Christianity still had a grip in the religious market place, with $85.6 \%$ of South Africans claiming to be Christians (STATSSA 2013):

The fact that Christianity is no longer the state religion and that people have the right to choose the religion of their choice implies that the religious sphere has become more competitive. From a different perspective, the relegation of Christianity has also opened the opportunity for the church to engage in interfaith dialogue with other religious groups not from a position of dominance, but equality (Bentley2013).

However, we do not have to accept the confinement of competition within the religious sphere uncritically. We would be naïve to confine religious competition in the sphere of religion in the current market-driven and neoliberal economy of individualist and corporate capitalism. Benjamin (1996) argued:

A religion may be discerned in capitalism - that is to say, capitalism serves essentially to ally the same anxieties, torments, and disturbances to which the so-called religions offered answers...Capitalism is a religion of pure cult, without dogma. (p. 288)

Furthermore, as decolonial scholars warn us, the demise of colonialism did not imply eliminating colonial structures and patterns. As Carrette and King (2005) argued:

In our contemporary context, the new rationale for colonialism is the conversion of entire communities and societies into individualised 'consumers' and compliant workers. With the rise of neo-liberalism in the late twentieth century, the primary ideological rationale for maintaining domination has become

TABLE 1: Religious affiliation in South Africa.

\begin{tabular}{lc}
\hline Religious affiliation & Percentage in RSA \\
\hline Christianity & 85.6 \\
Muslim & 2.0 \\
Ancestral, tribal, animist or other traditional religion & 5.0 \\
Hindu & 1.0 \\
Jewish & 0.2 \\
Other religions & 5.6 \\
Do not know & 0.3 \\
\hline
\end{tabular}

Source: Statistics South Africa

RSA, Republic of South Africa. 
the mythology of the 'free market' and the spread of democracy. This rhetoric hides the reliance of the capitalist enterprise upon these older colonial legacies. (p. 25)

In the current climate, Christian churches compete with other alternative religions and with capitalism and furthermore with other activities, which are marketed widely via various media platforms such as sports and other leisure activities that occupy the minds of the people. In this context, the church competes with a plethora of consumer-oriented choices. Therefore, in a free market, religion is viewed as a product to be marketed. As Finke and Iannaccone (1993) argued:

The market model views churches and their clergy as religious producers who choose the characteristics of their product and the means of marketing it. Consumers in turn choose what religion, if any, they will accept and how extensively they will participate in it. In a competitive environment, a particular religious firm will flourish only if it provides a product at least as attractive as its competitors.(p. 29)

The marketing of products plays an important role in our society and as such, explains some commercial components within religion. In this context of Christian churches, believers are sold faith products and services provided in some instances. It has become common to find church billboards on our highways, pastors featured on television channels advertised on our highways, Christian music (gospel), Christian movies, Christian books and so on. It would be an error to think about the commercialisation of religion by simply limiting it to services that are provided by local churches. Trending services provided by some neoprophetic churches include one-on-one sessions with the pastor or prophet, which come at a price (R5000, R7000, R10 000 and R15 000), as well as the sale of products such as holy water, anointing oil, bracelets (protective bands) and bumper stickers. Whilst some people may be irritated by the posting of flyers for deliverance services on the local roads within our cities, townships and villages (which are governed by the municipal by-laws), these are commonly for the entry-level players in the religious market; the big shots are on Digital Satellite Television (DSTV) and advertisements on television during primetime, and they have ways of generating media attention through the work of public relations consultants. The business world has also latched onto the religious sphere by providing platforms for the religious sector to publicise and sell religious products and services.

For example, it makes both religious and business sense when prophet Bushiri's gathering filled the First National Bank Stadium (FNB), which is owned by the City of Johannesburg but bears a commercial bank's name. It makes business sense for the city that can generate revenue from the rental fee, which it was not generating previously on New Year's Eve. It makes business sense for FNB, which acquires free advertising, as it is the brand name attached to the stadium. It also makes business sense for all the service providers who profit from the event - audio and visual companies, DSTV, security companies, including cash-intransit service and so on. It makes spiritual sense, as the event is able to fill the stadium, which implies that it is appealing to religious consumers.

In the current climate, what draws more people to churches' doorsteps are not the old models of evangelism - door-todoor evangelism or week- or month-long tent meetings rather, it is the packaging and promotion of faith as a valuable commodity. Furthermore, churches have to make it worthwhile for those who come to their doorsteps, otherwise they leave. For churches to remain competitive, they must by implication, engage in more marketing and promotions on various platforms. As Einstein (2008:21)observed, 'Increased marketing means increased competition, which in turn generates more marketing'. The megachurches have learned to market themselves by offering services and products, which appeal to religious consumers, and they are able to utilise secular platforms to position themselves.

The concern that some churches are becoming commercialised, whilst it has some validity; it is problematic. In our view, the question is misleading: there has never been a point at which the church was not commercialised - with or without state sponsorship. Churches as institutions not only rely on the Word and Spirit for their operation but also on monetary resources. What has changed in our commercial age is the intensity with which it happens. Whilst some churches might be selling products directly to the consumers, some are selling them through the internet. One example is the online Catholic Shop, which sells things such as anointing oil, medals, prayer cards, incense granules, crucifixes, branded items, bracelets and necklaces (rosaries) with the cross. ${ }^{6}$ Does the selling of services and products become a problem when certain churches do it, but not when performed by other churches? In our view, for some of the long-established church traditions, it may even be that the commercial wings are independent of the church as business wings, which no longer have direct links to the church, but function as service providers.

The church lives in a competitive and continually changing environment, and it has to learn to adapt if it is to survive. In the process of learning to adapt and survive, blunders and mistakes do happen, just as in other spheres of life such as politics and economics. Within Christianity, a sense of competition amongst churches is also discernible. As churches and pastors compete for the market share, it opens up room for bizarre practices as churches seek to draw followers. In this process, manipulations and exploitative tendencies often creep in and, therefore, the need for awareness and protection for faithul consumers.

\section{Church brands: Church competition and brand prophets}

In the religious sector, competition is not simply between alternative religions. In our context, in which Christianity

6.See https://www.catholicshop.co.za/. 
enjoys a large share of the population, there is internal competition within Christianity. Whilst this competition goes way back in the history of the Christian church, it reached a new level during the much-celebrated Reformation of the sixteenth century, as new churches were established and new brand names emerged, and so we speak of the Lutheran Church (named after Martin Luther), the Church of England (or Anglican Church, named after the nation of England, Reformed Church (a name that reflects the zeit geist; it was used during the Reformation period within classical Protestantism to distinguish the new churches from the Roman Catholic Church, which was regarded as 'unreformed'), the Methodist Church (a name derived from a movement associated with the teachings of John Wesley) ${ }^{7}$ and the Episcopal and Presbyterian Churches (named for their forms of church government). Since then, because of various factors which came into play, such as colonial expansion, schisms and changing environment, new church brands continued to emerge. Thus, the church is not monolithic and monovocal but pluralistic and plurivocal. This in turn implies that the church in its unity is also riddled with internal competition: different church traditions compete against each other and so do churches within the same tradition.

Thus, in today's culture of individualist or consumerist spirituality, consumers within the Christian faith have alternatives to choose from. This freedom is guaranteed in our Constitution. Within this constitutionally guaranteed liberty, some churches, especially the mainline churches, are dwindling in numbers; however, other churches are growing, especially the pentecostal or charismatic churches and amongst these more so the neoprophetic churches. ${ }^{8}$ Some of the distinct features of the neoprophetic churches are the following (Daswani 2015; Kalu 2013; Omenyo \& Arthur 2013; Omenyo \& Atiemo 2006; Ramantswana 2018,2019):

- Prophetic office is the centre of neoprophetic churches: The neoprophetic churches may also be described as prophetcentred church. The prophet is regarded as a person in whom the power of God resides - the power to heal, deliver, bless, curse and also to utter prophecies.

- Prophecy is at the core of the liturgy of neoprophetic churches: Prophetic utterances are an essential component of church liturgy with calls such as, 'prophesy man of God'or 'prophesy woman of God', often made for the prophet to prophesy.

- Emphasis on addressing personal needs: The neoprophetic churches focus on addressing consumer needs - healing, deliverance, prosperity, fresh personal divine words and miracles, and therefore, promises for such things are often declared before hand as special services are organised under titles such as 'Prophetic Service',

7.It is also common in our South African context to refer to those in the Methodist church as amaWesele ('the Weslyians').

8.It should be noted, however, that the growth of the neoprophetic churches is not only based on attracting solely new believers but also believers cross the floor from the mainline churches. There are many factors that influence such floor crossing, as believers are also consumers who want to meet certain spiritual needs in their lives. believers are also consumers who want to meet certain spiritual needs in their lives.
The poor are also drawn by those churches that promise a way out of poverty The poor are also drawn by those ch
through their messages (Kgatle 2017).
'Deliverance Service', 'Night of Fire', 'Miracles and Healing Service'. Thus, once the things are declared, the belief amongst the followers is that it is bound to happen.

Those who gravitate towards the neoprophets do so longing to receive personal divine word, deliverance, healing, blessings and prosperity. Furthermore, the prophets assume the role of intermediaries between the market economy and the spiritual realm to satisfy the seekers' needs. As Daswani noticed, 'Through their prayers and prophecies, prophets connect those "without" with what they need or desire, transforming values across different realms - converting culturally recognisable spiritual power into economic power'. Thus prophets and their churches as intermediaries are transformed into brands of their own.

\section{Church brands and brand prophets}

In the current climate, there is a shift in the way that churches are branded. Traditionally, church denominations were the main brands - Catholic, Reformed, Protestant, Anglican, Presbyterian, Baptist, Episcopal, Zionist, Apostolic, Pentecostal or Charismatic. However, the church landscape has been changing - we now have independent or interdenominational or nondenominational churches. Parachurch organisations tend to prefer to operate under the tag of interdenominational or ecumenical to avoid denominational constraints. In this pluralistic environment, local churches are branded in the sense that they have names, logos, vision statements and mission statements in order to distinguish themselves. As Einstein (2008) argued:

That religious products would turn to branding makes perfect sense in the current cultural environment. To remain relevant in our commercial culture means at a minimum being heard among the multitude of competing messages. Branding faith becomes shorthand for reaching the new religious consumer. (p. 13)

Another significant development in the South African context is the mega-Pentecostal churches and the megaProphetic churches. With the mega-Prophetic churches, there is a sense in which they also serve other churches. Thus, prophets and believers who belong to other churches travel to churches such as Enlightened Christian Gathering (ECG) and Alleluia International Ministries (AIM) for spiritual revival and to meet their spiritual needs. These churches market themselves as providing services not only for their own members but also for members of other churches. The idea of catholicity finds new significance within these churches, whose pastors provide services to believers across denominations who come to them with their spiritual longings. These churches have an international or global reach, which is evidenced by the continual visits of international guests.

Thus, the South African churches compete with each other, but in the face of globalisation, believers are willing to travel 
internationally to acquire their spiritual fulfilment. Prior to the national lockdowns in South Africa and other countries, some followers of the Prophet TB Joshua used to travel from their home countries to The Synagogue, Church of All Nations (SCOAN) in Nigeria for an encounter with the prophet. The death of over a hundred believers at SCOAN in 2016, when the guest house at SCOAN collapsed, speaks to the reality of believers willing to go to great lengths for their spiritual satisfaction. These churches cater to visitors' various needs, with the main emphasis being on prophesies, miracles and deliverance. Other characteristic features of such churches include the sale of anointing oil, holy water, bracelets and bumper stickers. In such churches, the main brand name is not that of the church but that of the prophet or the pastor.

This shift has been unfolding since televangelists' advent, and the Christian circle is slowly and surely adjusting to it. The shift from church name brands to brand pastors implies that it is no longer so much the name of the church that draws the crowds, but the name of the pastor. Some of the famous brand pastors in our country include Chipiliro Gama, who operates under the brand name Prophet Shepherd Huxley Bushiri (or Major 1; his church is the ECG), Pastor Alph Lukau (Alleluia Ministries International), Pastor Ray MacCauley, Pastor At Boshoff (Christian Revival Church), Bishop Mosa Sono (Grace Bible Church) and Pastor Paseka Motsoeneng (Mboro). These pastors' brand names are enhanced through extensive use of media - television, radio, internet services (social media, YouTube, etc.), publishing - which boost the names and roles of the pastors beyond that of the church.

Some refer to these pastors more negatively as 'personality cults', considering the tendency of the followers to unquestionably submit to the mand hold them in very high regard (Thumma \&Travis2007:55). Classified as such considering the absolute submission of the believers to the prophets or pastors, which may be viewed as 'blind following'. Others refer to these pastors as 'celebrity pastors', considering the large following they have and their ability wherever they go for events to draw large crowds and fill large auditoriums and stadiums.

With the rise of brand prophets or pastors, as Ramantswana (2018) argued, there is a shift from a place-centred pilgrimage to a person-centred pilgrimage. With some brand prophets comes emphasis on the divine power that resides in the person, which in turn is manifested through the person's ability to prophesy, heal, cast out demons and pronounce blessings. Therefore, people are willing to pay for travel and for audiences with these brand prophets or pastors.

The phenomenon of brand prophets or pastors is not necessarily new - it reflects the practice in the early church in which names of apostles and church fathers carried authority. The believers identified with those who started their churches (Cephas, Paul, Apollos; see 1 Cor 1:1-17; 3:22-23) and with those who eventually became church fathers, who were regarded as authoritative figures in the life of the church
(Clement of Rome, Ignatius of Antioch, Polycarp of Smyrna, Papias of Hierapolis, Justin Martyr, Irenaeus of Lyons, Clement of Alexandria, Origen of Alexandria, Athanasius of Alexandria, John Chrysostom, Cyril of Alexandria, Tertullian, Cyprian of Carthage, Hilary of Poitiers, Ambrose of Milan, Pope Damascus I, Jerome of Stridonium, Augustine of Hippo, Pope Gregory the Great, Isidore of Seville). This is not new to Catholics, who look back to the times of St. John Vianney and Mother Teresa of Assis Chiara Lubrica.

Whilst some people may frown on the idea of brand prophets and equate it with the worship of humans, we caution those who live in glass houses not to throw stones. Some of the critics of these brand prophets have a colonial mindset that makes them proud to be Lutherans, Calvinists, Wesleyans or some other brand, and they are prepared to die for the theological ideas of dead figures (Martin Luther, John Calvin, John Wesley and so on). Although dead, these figures' brands continue to live on, and their ideas are cherished and propagated wherever churches associated with their names are established. What we have is simply a different spiritual orientation: Some are prepared to die for the theological ideas of dead people, whereas others are prepared to die for the spiritual services they receive from living prophets. Many of the current-day 'brand prophets' are not canonised and will not even reach that level - they will die and be forgotten.

When people travel locally in South Africa and are willing to pay R5000, R7000 or R10000 for special services or for a one-on-one audience with the prophet or man of God, or when they travel to Nigeria or anywhere else, spending exorbitant sums of money for the same reason, do we have to regard it as abuse of religion, or is it an exercise of their constitutional right? Do we have to guard people from exercising their constitutional right? In our view, what drives believers nowadays is the consumer mentality or perception concerning price, quality and value. Scholars differentiate between perceived quality, the consumer's judgement about the superiority of the service or the product and objective quality, the measurable and verifiable superiority of the service or the product. With megachurches and brand pastors, image and problem-solution advertising strategies are utilised to convince consumers of the quality of the services or product they offer (Dodds \& Monroe1985; Garvin 1983; Holbrook \& Corfman 1985; Parasuraman, Zeithaml \& Berry1985; Zeithaml1988).

\section{Image}

People like to be associated with a good brand, so megaProphetic churches (and other megachurches not necessarily associated with the prophetic movement) tend to invest in state-of-the-art facilities, branding, audio and visuals, productions and marketing. This is not an era of theological revolution, so it is not theological sophistication, confessions and creeds which draw the largest crowds nowadays; rather, this is the fourth industrial revolution era, which is about sophistication and technological advancement. Thus, mega-Prophetic churches present a positive image as 
thriving and dynamic churches, which find ways to navigate in the continually changing environment. People will fill four or five state-of-the-art auditoriums to watch a pastor or prophet preaching on a big screen in a church modelled after a cinema. If the product is appealing to the consumers, they will go for it.

\section{Problem-solution advertising}

In our context, the brand prophets and their churches present themselves as offering solutions and utilise three main strategies: firstly, they televise incidents that portray real and life-changing spiritual encounters with the man of God of prophecy, people going into trances, healing, demonic encounters and so on. These are intended to project the man of God as powerful. Secondly, the prophets focus on positive and affirming messages. Thirdly, the prophets present themselves as having powers to bind evil forces and to break curses. As Einstein (2008) pointed out:

Alas, unhappy endings do not make for good television, particularly television that has to compete in a marketplace of entertainment. Instead, success, happiness, prosperity, empowerment, redemption - these are the messages of televised religion.(p. 145)

Fourthly, testimonies of success, healing, deliverance and life-changing experiences as becoming part of the church tend to be prominent features to promote the church or the pastor.

In our current culture of consumption, people tend to view religion as a commodity, and they are willing to purchase or spend towards it just as they do towards other products. Whether the quality is perceived or objective, once the customer is convinced of the service or the product which the church or pastor is offering, there is willingness to pay or give more towards the church. In our South African context, free services and products are usually equated with poor quality. For example, state-provided lawyers are considered more likely to lose cases than private lawyers. Similarly, free public hospitals and clinics are equated with poor service, whereas private hospitals are regarded as providing superior service. This attitude may be why churches that continue to operate through the traditional models struggle to grow, whereas those adopting the business model are thriving.

A commercialised church's goal is to keep the church growing by attracting more people and getting current members to be loyal to the services and products. Therefore, in this model, it is essential to know the consumers' needs and offer them services that will make them continue to come back. This does not imply that this model is without its challenges. For example, there is the danger of toning down the Scriptures to satisfy customers' needs and thereby become faithful to the customer but not faithful to the Lord of the service. As Scripture warns:

The time will come when men will not put up with sound doctrine. Instead, to suit their own desires, they will gather around them a great number of teachers to say what their itching ears want to hear. (2Tm4:3NIV)

\section{Clergy malfeasance through promising miracles, healings and prosperity}

Like politics, economy, sports and any other field, the religious sphere is not immune to fraudulent activities. For the CRL Rights Commission, the commercialisation of religion is tied to the issue of healing and miracles. The problematic area relates to the advertisement of miracles, healing and prosperity (CRL Rights Commission 2017:9):

If religious leaders claim they can perform certain miracles and charge people for such activities, are they not accountable to ensure that they deliver on those promises? (p. 9)

The attempt to determine if the religious leaders are delivering on their promises would have its challenges: Firstly, how can the church or the religious leader prove that the healing or miracle occurred as a result of divine intervention or power and not from a placebo effect? Secondly, how can it be proved that the healing or miracle did not occur as a result of the religious leader's lack of power of ability or God's inability to heal? Thirdly, how can it be proved whether a person failed to be prosperous because of the person's own inability or the pastor's inability or God's inability or it simply not being God's will for the person to be prosperous? Or that the person became prosperous as a result of hardwork and not because of the prophet's ability or God's intervention? Fourthly, can miracles be regulated? Fifthly, if miracles can be regulated, then would they not cease to be miracles?

With regard to religious healing, some scholars tend to differentiate between 'religious healing'and 'spiritual healing', which can be performed by someone who does not necessarily subscribe to a given religious system. ${ }^{9}$ In this sense, spiritual healing is performed by someone who has special abilities but does not identify with a particular religion. From this perspective, the gift of healing is not viewed as only accessible to pastors or prophets or religious practitioners, but as something open for anyone who is willing to undergo particular training to acquire the skills of spiritual healing (Cohen 2002; Kok Sui 1990; Smith 2000). As Cohen (2002:375) argued, when spiritual healing is accommodated within the public health care system, it has to be subject to 'regulatory controls similar to those imposed on other healthcare professionals'. Cohen (2002) continued:

Spiritual healing touches the boundary between medicine and religion, science and faith, intellect and uncertainty. Legal rules, in addition to safeguarding the public health, also codify political

9.According to Booth (1991:20), " people can be spiritual without being religious - and religious without being spiritual. Religion is a belief system organised around a prophet, teacher or set of human precepts. Spirituality is the ability to discover and use our own unique specialness, and religion does not always help us do that'. For Aldridge (2000:20), spirituality is a subjective matter, whereas religion is social and requires subscription to institutionalised sets of beliefs. Cohen et al. (2001:31-32) requires subscription to institutionalised sets of beliefs. Cohen et al. (2001:31-32) stated, The "term" spirituality tends to be used as a broader term to refer to that which brings significance, purpose and direction to people's lives. The person who has spiritual beliefs and interests searches for (usually nonphysical) sources of meaning, life, wholeness, healing and hope. The various forms of spirituality may be fluid and individual taking no classical religious form, or they may be crystallised in the beliefs and practices of a specific religious community ... The term "religion"... tends to be associated with beliefs, practices and ethical teachings of specific religious bodies and traditions'. 
attempts to preserve professional monopolies. In so doing, such rules scrystallise cultural belief systems about what professional healers can or should be able to do. Thus, it is increasingly important to explore the nexus between legal rules, ethical codes, religious values, and medical culture. Probing the regulatory edges of abuse of power at the borderland of religion and medicine begins to tease out unstated assumptions about the ultimate meaning of human affliction and the health care professional's role in the process of healing. (p. 426)

In prophetic churches, prophets occupy an interesting position - they do so to speak and function as intermediaries or spiritual brokers between God and the people, as they claim divine powers to heal, prophesy and transfer divine blessings, but they also establish relationships in which the believers trust them and become vulnerable to them. In this relationship, there is potential for abuse by the prophets because of the authority they have on the basis of the position. The challenge that currently besets the religious sector with regard to healings, miracles and prosperity is clergy malfeasance, which is misconduct of church officials such as pastors who intentionally commit acts that are illegal, but are hard to prove as such. For Cohen, clergy malfeasance amounts to 'the exploitation and abuse of a religious group's believers by trusted elites and leaders of that religion'. As Van Eck and Van Twist (2014) observed:

As white-collar crime, clergy malfeasance involves persuasion and guile and often the process is open to ambiguity - it is not entirely clear that whatever is happening is fraudulent. This is either because the victims are often unaware that fraud has taken place or that their contributions were used for other purposes, or they may see the process in a favourable light because of the context in which it occurs. (p. 5)

Returning to the event of 24 February 2019, the event of the resurrection of a dead man, we should state categorically that for us, the so-called resurrection of a dead man - in reality a man who was already alive when he was brought to the church - bears the marks of a preplanned and staged event and therefore a fake miracle. In our view, the 'resurrection of the dead man' was a subterfuge intended to boost the prophet's image so he could set himself up as a powerful man of God. If the stunt had not been revealed as fraudulent, it would have been one of the greatest hoaxes ever pulled off.

For many of the people who were present at Alleluia Ministries International on that day but not close enough to see things as they unfolded, the atmosphere would have been electrifying, especially when they saw someone who had been taken out of a coffin walk up and down and run in front of the church. However, the event was staged so cleverly that faithful followers have been willing to believe the explanation of their pastor. Whilst the pastor was willing to take credit for resurrecting a man from the dead on the day of the event, is it surprising that when there was a backlash after the hoax had been revealed, the pastor explained his actions to the congregation by blaming the current generation for being 'cold'to the teachings of the Bible on the resurrection.
As already highlighted, the prophecies, healing, miracles and prosperity claims serve as an important marketing tool - it is these factors that pull the masses to some of the neoprophetic churches. The tendency evident in many of the neoprophetic churches is that the prophets are eager to display their power and boost their brand by doing what others have not performed before. Therefore, the competition amongst the prophets open room for bizarre practices and fake miracles and healings as the prophets seek to outdo each other. This is exacerbated by the pressure to grow the church and to retrain the people who are drawn to the church is likely one of the factors that contribute to the fabrication of miracles and healings. The pressure is on those like Lukau, who from the look of things are high up the ladder running a mega prophetic church and are under pressure not simply to retain members but to avoid losing ground and falling to the dust. The pressure for those at the bottom is not only the desire to grow the church and the longing for power and affluence but also the aspiration to attain the status of powerful celebrity prophet or pastor. Furthermore, the pressure to pull the masses and affluence is also leading some prophets to engage in syncretistic behaviour by engaging with what in biblical terms are forces of evil or darkness in order to acquire prophetic, healing and miraculous ability (see Ramabulana 2018). Lindhardt (2014) noticed that in Tanzania, there are pastors within the pentecostal or charismatic denominations, who are getting their powers from traditional healers or witchcraft and that some of these pastors from time to time visit Nigeria to obtain occult powers.

It is unfortunate that some prophets or pastors would go to the extent of fabricating prophecies, miracles and healings in order to pull crowds to enhance their churches. However, this is not characteristic of most of the churches in South Africa, rather, it is risk, which should be associated mainly with the neoprophetic churches.

\section{Recommendations and conclusion}

The CRL Rights Commision in an attempt to address the challenges posed by the bizarre practices amongst some churches has recommended the following amongst other things: the establishment of the Peer-Review Committee (PRC), which will be composed of representatives from various religions in South Africa. Thus, the body would function as a self-regulatory body that would deal with concerning issues arising within the religious organisations or associations. The CRL Rights Commission with the introduction of the PRC would also function as a judicial body or regulatory body that will be the final arbiter in matters of religion in terms of section 22 of the Constitution. Our interest here is not to engage the CRL Rights Commission's recommendations; however, a brief comment ons this recommendation is necessary. ${ }^{10}$ We do not view the idea of CRL Rights Commission functioning as juristic body as necessary considering the already available judicial system in the country that can handle cases and matters arising from 10.For further discussion on CRL recommandations, see Banda (2019); Freedom of Religion South Africa (2017); Henrico (2019). 
the religious sector. Religious bodies or organisations cannot be regulated in terms of what they believe. However, the principle that no one is above the law applies to religious bodies or organisations and those who function within those bodies be it as leaders, pastors, prophets and in any other capacity. The freedom of religion is guaranteed in the constitution of South Africa, however, that does not set any religious body above the law. As Henrico (2019) argues regarding the freedom of religion:

The freedom is spiritual in nature, and save for instances of infractions of the civil or criminal law, there is simply no reason to regulate religious freedom in a free and democratic society. This very aspect of the right in question, namely that it is one which is so vexed with personal beliefs and views, make it more suitable that in instances where one seeks to limit religious freedom a court, as opposed to a regulatory body, should be the adjudicator. (p. 15)

Therefore, we agree with the observation of Freedom of Religion for South Africa (2017) that:

South African law and its legal system is sufficient to deal with any criminal activity, whether committed by a religious leader or an ordinary person. It simply needs to be enforced. (p. 4)

We recommend the following concerning the issue of religion and commerce:

Firstly, the view that religion and commerce are at odds with each other is irrational and illogical. For religious bodies to function and operate optimally, they require funds and therefore, there are various means through which religious bodies raise funds. Furthermore, in some instances, religious and employee personnel in their organisations get their remuneration from those organisations. Religious bodies use various means to raise their funds to fund their operations. In the case of Christian churches and organisations, the giving is commonly through freewill giving and tithing.

Secondly, if religious bodies or religious practitioners in the process of exercising their religious freedom exploit people, undermine human dignity or engage in abusive tendencies financially or otherwise should be held accountable. The public has a moral obligation to raise public awareness. In case of irregularities or violation of the law, the moral obligation to report such instance to the Public Protector and the South African Human Rights Commission or to open a case for investigation.

The case of fraud and money laundering against the fugitive prophet Shepherd Bushiri and his wife Mary and others involved investigated by the Directorate for Priority Crime Investigation (Hawks) is one example to prove that there are systems already in place to deal with cases of financial irregularities and violation of the law. Furthermore, following a meeting with the CRL Rights Commission, the South African Revenue Service (SARS) issued a statement on 26 January 2018 highlighting the need for churches to comply with their tax obligations. Thus, freedom of religion does not imply freedom from regulation from the institutions of the country intended to regulate the flow of money.

Thirdly, religious bodies should be willing to operate in transparent ways in terms of their finances to their followers and be accountable to their followers. Furthermore, the bodies mandated by the Constitution and the legal systems in place have the right to exercise their obligation towards religious bodies and to hold them accountable.

In conclusion, we return to the question of this study: Have some churches gone too far? Whilst it may be acknowledged that there are some rotten tomatoes in the batch, it does not necessarily follow that the whole batch is rotten. However, failure to deal with the rot will result in the spoiling of the whole basket. Some churches and prophets or pastors have gone too far, but these may be few considering the number of pastors and churches.

The church has the responsibility to adapt in the current commercial age to remain relevant and compete in the open market. In the neoliberal market, self-regulation of the market is idealised; however, it cannot be so when people are exploited and abused. Those who violate the law when exercising their religious freedom violate should be prosecuted within the prescripts of the law.

\section{Acknowledgements Competing interests}

The authors declare that they have no financial or personal relationships that may have inappropriately influenced them in writing this article.

\section{Authors' contributions}

H.R. and I.S. equally contributed to the design and implementation of the research, to the analysis of the results and to the writing of the manuscript.

\section{Ethical considerations}

This article followed all ethical standards for research without direct contact with human or animal subjects.

\section{Funding information}

This research received no specific grant from any funding agency in the public, commercial or not-for-profit sectors.

\section{Data availability statement}

Data sharing is not applicable to this article as no new data were created or analysed in this study.

\section{Disclaimer}

The views and opinions expressed in this article are those of the authors and do not necessarily reflect the official policy or position of any affiliated agency of the authors. 


\section{References}

Aldridge, D., 2000, Spirituality, healing and medicine: Return to the silence, Jessica Kingsley, London.

Banda, C., 2019, 'Redefining religion? A critical Christian reflection on CRL Rights Commission's proposal to regulate religion in South Africa', Verbum et Ecclesia 40(1), 1-11, a1948. https://doi.org/10.4102/ve.v40i1.1948

Benjamin, W., 1996, 'Capitalism as religion', in M. Bullock \& M.W. Jennings (eds.) Walter Benjamin: Selected writings 1913-1926, vol. 1, pp. 288-291, Harvard University Press, Cambridge.

Bentley, W., 2013, 'Defining Christianity's "Prophetic Witness" in the post-apartheid South African democracy', Studia Historiae Ecclesiasticae 39(1), viewed 04 March South African democracy', Studia Historiae Eccles
2019, from http://hdl.handle.net/10500/9981.

Booth, L., 1991, When God becomes a drug: Breaking the chains of religious addiction and abuse, Jeremy P. Tarcher, Los Angeles, CA.

Carrette, J. \& King, R., 2005, \$elling spirituality: The silent takeover of religion, Routledge, London.

Cohen, C.B., Wheeler, S.E., Scott, D.A. \& Anglican Working Group in Bioethics, 2001 'Walking a fine line: Physician inquiries into patients' religious and spiritual beliefs', The Hastings Center Report 31(5), 29-39. https://doi.org/10.2307/3527702

Cohen, M.H., 2002, 'Healing at the borderland of medicine and religion: Regulating potential abuse of authority by spiritual healers', Journal of Law and Religion 18(2), 373-426. https://doi.org/10.2307/1602269

CRL Rights Commission, 2017, Report of the hearings on commercialisation of religion and abuse of people's belief systems, viewed 05 July 2019, from https://www.gov. $\mathrm{za} / \mathrm{sites} /$ default/files/gcis_document/201708/report-commecializationofreligion andabuseofpeoplesbelievesystems.pdf.

Dodds, W.B. \& Monroe, K.B., 1985, 'The effect of brand and price information on subjective product evaluations', in E.C. Hirchsman \& M.B. Holbrook (eds.) Advances in consumer research, vol. 12, pp. 85-90, Association for Consumer Research, Provo, UT.

Einstein, M., 2008, Brands of faith: Marketing religion in a commercial age, Routledge, London.

Finke, R. \& lannaccone, L.R., 1993, 'Supply-side explanations for religious change', The Annals of the American Academy, AAPSS 527(1), 27-39. https://doi.org/10.1177/ Annals of the American

Freedom of Religion South Africa, 2017, Open letter to the CRL Rights Commission on its final report on the 'Commercialisation of Religion and Abuse of People's Belief Systems'.

Garvin, D.A., 1983, 'Quality on the line', Harvard Business Review 61, 65-73.

Harvey, D., 2005, A brief history of neoliberalism, University Press, Oxford.

Holbrook, M.B. \& Corfman, K.P., 1985, 'Quality and value in the consumption experience: Phaedrus rides again', in J. Jacoby \& J. Olson (eds.), Perceived quality, pp. 31-57, Lexington Books, Lexington.

Kgatle, M.S., 2017, 'The unusual practices within some Neo-Pentecostal churches in South Africa: Reflections and recommendations', HTS Theological Studies 73(3), 1-8. https://doi.org/10.4102/hts.v73i3.4656

Lindhardt, M., 2014, 'Miracle makers and money takers: Healers, prosperity preachers and fraud in contemporary Tanzania', in A. Van Eck \& D. Van Twist (eds.), Minority religions and fraud in good faith, pp. 253-180, Ashgate, Surrey.
Narsiah, S., 2002, 'Neoliberalism and privatisation in South Africa', GeoJournal 57, 3-13.

Omenyo, C.N., 2011, 'Man of God, prophesy unto me: The prophetic phenomenon in African Christianity', Studies in World Christianity 17(1), 30-49. https://doi. org/10.3366/swc.2011.0004

Omenyo, C.N. \& Arthur, W.J., 2013, 'The Bible says! Neo-prophetic hermeneutics in Africa', Studies in World Christianity 19(1), 50-70. https://doi.org/10.3366/ swc.2013.0038

Omenyo, C.N. \& Atiemo, A.O., 2006, 'Claiming religious space: The case of neoprophetism in Ghana', Ghana Bulletin of Theology, New Series 1(1), 55-68.

Oswalt, C., 2003, Secular steeples: Popular culture and the religious imagination, Trinity Press International, Harrisburg.

Parasuraman, A., Zeithaml, V.A., \& Berry, L., 1985, 'A conceptual model of service quality and its implications for future research', Journal of Marketing 49(4), 41-50. https://doi.org/10.1177/002224298504900403

Ramabulana, M.K., 2018, Church Mafia: Captured by secret powers: An untold African narrative, Makhado Freedom Ramabulana, self-published.

Ramantswana, H., 2018, 'From the blood of Abel to the blood of Zechariah to the blood of victims who died at SCOAN: A critical reflection', in M. Masenya \& K.N. Ngwa, Themes and trends from our pots and our calabashes: Navigating African biblical hermeneutics, pp. 103-120, Cambridge Scholars Press, Cambridge.

Ramantswana, H., 2019, 'Prophets praying for, or perying on people's faith: A reflection on prophetic ministry in the South African context', In Luce Verbi/In Die Skriflig 53(4), 1-8. https://doi.org/10.4102/ids.v53i4.2495

Republic of South Africa, 1996, The constitution of the Republic of South Africa viewed 05 July 2019, from http://www.justice.gov.za/legislation/constitution/ SAConstitution-web-eng.pdf.

Resane, K.T., 2016, “'And they shall make you eat grass like oxen" (Daniel 4: 24): Reflections on recent practices in some New Charismatic Churches', Pharos Journal of Theology 98, 1-17.

SARS, 2018, 'SARS' compliance intervention in religious sector, viewed 16 September 2020, from https://www.sars.gov.za/Media/MediaReleases/Pages/26-January2018---SARS-compliance-intervention-in-religious-sector.aspx.

Smith, L.L., 2000, Called into healing: Reclaiming our Judeo-Christian legacy of healing touch, Healing Touch Spiritual Program, Arvada.

Sui, C.K., 1990, Pranic Healing, Red Wheel/Weiser, Newburyport.

STATSSA, 2013, General household survey, 2013, viewed 13 July 2019, from https:// www.statssa.gov.za/publications/P0318/P03182013.pdf.

Thumma, S. \& Travis, D., 2007, Beyond megachurch myths: What we can learn from America's largest churches, Jossey-Bass, San Francisco, CA

USA, 1791, The Bill of Rights, First Amendment Act, viewed 13 July 2019, from https://www.constitutionfacts.com/content/constitution/files/Constitution BillOfRights.pdf.

Van der Vyver, J.D. \& Green, M.C., 2008, 'Law, religion and human rights in Africa: An introduction', African Human Rights Law Journal 8(2), 337-356.

Van Eck, A. \& Van Twist, D., 2014, 'Introduction', in A. Van Eck \& D. Van Twist (ed.), Minority religions and fraud in good faith, pp. 1-15, Ashgate, Surrey.

Zeithaml, V.A., 1988, 'Consumer perceptions of price, quality, and value: A means-end model and synthesis of evidence', Journal of Marketing 52(3), 2-22. https://doi. org/10.1177/002224298805200302 